

Rec. Nat. Prod. 14:4 (2020) 256-268

records of natural

publications

products

\title{
Ent-kaurene Diterpenoids from Sideritis lycia with Antiviral and Cytotoxic Activities
}

\author{
Turgut Kilic $1^{*}$, Gulacti Topcu 2*, Ahmet C. Goren 2 2,3, \\ Zeynep Aydogmus ${ }^{4}$, Ali Karagoz ${ }^{5}$, Yasar K. Yildiz ${ }^{6}$ and Irfan Aslan ${ }^{7}$
}

\author{
${ }^{1}$ Faculty of Necatibey Education, Ballkesir University, 10100, Balikesir, Türkiye \\ ${ }^{2}$ Faculty of Pharmacy, Bezmialem Vakıf University, 34093, Fatih, Istanbul, Türkiye \\ ${ }^{3}$ Drug Application and Research Center, Bezmialem Bezmialem Vaklf University, 34093, Fatih, \\ Istanbul, Türkiye \\ ${ }^{4}$ Faculty of Pharmacy, Istanbul University, 34116, Beyazlt, Istanbul, Türkiye \\ ${ }^{5}$ Faculty of Science, Istanbul University, 34459, Vezneciler, Istanbul, Türkiye \\ ${ }^{6}$ Buca Education Faculty, Dokuz Eylul University, 35100, Izmir, Türkiye \\ ${ }^{7}$ Faculty of Humanities and Social Sciences, Ankara Yildirim Beyazit University, 06760, Ankara, \\ Türkiye
}

(Received August 21, 2019; Revised November 01, 2019; Accepted December 16, 2019)

\begin{abstract}
The genus Sideritis (Lamiaceae) is represented by 45 species ( 54 taxa) in Anatolia with high endemism ratio $(74 \%)$, and Turkey is one of the gene centers of the genus along with Spain. Acetone extract of the aerial parts of Sideritis lycia afforded eight known ent-kaurene diterpenoids, structures of which have been identified as linearol, isolinearol, isosidol, sidol, siderol, sideridiol, 7-epi-candicandiol and foliol through ${ }^{1} \mathrm{H}$ NMR, ${ }^{13} \mathrm{C} \mathrm{NMR}$ and mass spectroscopic analyses. Cytotoxic and antiviral activities of the acetone extract, linearol, sidol and isosidol were investigated together with insecticidal activity of species. The antiviral index of linearol, isosidol and acetone extract of $S$. lycia were determined as 2.31, 2.01 and 2.58, respectively, except sidol. 7-Epi-candicandiol was found to be the most active diterpene against a series of cancer cell lines with $\mathrm{ED}_{50}$ values; $\mathrm{KB}(13.3 \mu \mathrm{g} / \mathrm{mL})$, COL-2 $(11.8 \mu \mathrm{g} / \mathrm{mL})$, LU1 $(17.9 \mu \mathrm{g} / \mathrm{mL}), \operatorname{LNCaP}(14.9 \mu \mathrm{g} / \mathrm{mL})$ and A2780 $(9.0 \mu \mathrm{g} / \mathrm{mL})$. Activity results of this study indicated that ent-kaurane diterpenes have potential to be considered as antiviral and cytotoxic lead compounds.
\end{abstract}

Keywords: Sideritis lycia; diterpenoid; NMR and mass spectroscopy; antiviral; cytotoxic activity; insecticidal activity. (C) 2020 ACG Publications. All rights reserved.

\section{Introduction}

Lamiaceae is one of the largest families with 46 genera and 603 species in Flora of Turkey with about 12.000 taxa [1,2]. The genus Sideritis L. (Lamiaceae) includes approximately 150 species of annual and perennial plants distributed in different parts of the world, mainly in the Mediterranean basin. Turkey is one of the gene centers for the genus Sideritis along with Spain [1-5]. In Turkey, 45 Sideritis species, 38 being endemic, are growing naturally. Therefore, Sideritis L. is one of the most endemic genera of the Flora of Turkey [4-6]. Four of them (totally 5 taxa), which are annual, are included in Burgsdorfia and Hesiodia sections; these are $S$. lanata L., S. romana L. subsp. romana, $S$. curvidens Stapf, S. montana L. subsp. montana, and S. montana L. subsp. remota (d'Urv.) P.W. Ball ex Heywood $[3,5,6]$. The other species are perennial belonging to Empledocia section in Turkey. As a

\footnotetext{
* Corresponding authors: E-Mail: tkilic@balikesir.edu.tr (T.Kilic); gtopcu@bezmilaem.edu.tr (G.Topcu) The article was published by ACG Publications 
result of a detailed morphological and anatomical revisions of Sideritis species growing in Turkey, number of the species has increased to 45 (54 taxa) [1,8].

Sideritis species have been used as herbal tea, called mountain tea or valley tea in Turkey. They are widely used in treatment of gastrointestinal disorders, common cold and as diuretic [7]. They have been used as antispasmodic, gastro-protective, anti-inflammatory, antidepressant and anti-stress agents in Turkey and throughout Mediterranean region [9-11]. There are a number of biological activity studies, carried out by various groups in Turkey, Spain, Balkans and other countries [12-14], particularly for their antimicrobial [15], antiulcerative and anti-inflammatory [16-18], cytotoxic, apoptotic, antispasmodic [19], antioxidant, and antinociceptive activities [20,21].

Most of the chemical studies on Turkish Sideritis species, particularly for diterpenic structures have been carried out by Topcu's group including Sideritis athoa [22], S. argyrea [23], S. dichotoma [24], S. sipylea [24], S. trojana [25], S. leptoclada [26], S. stricta [27], S. tmolea [28], S. condensata [29], S. arguta [30], S. congesta [31], S. niveotomentosa [32], S. brevibracteata [33], and several other Sideritis species [34]. Antioxidant and anticholinesterase activities of ent-kaurane diterpenoids from Sideritis arguta and S. congesta were studied by Topcu group, and 7-epi-candicandiol and sideroxol showed the highest butyrylcholinesterase inhibitory activity among the screened compounds, including the standard compound galanthamine $[30,31,33,35]$. Insecticidal activity of some Sideritis species were also investigated in the previous studies [29, 36].

In Turkey, some of Sideritis species were studied phytochemically for their flavonoids, flavonoid glycosides and phenylpropanoids [37] rather than the pure di- and triterpenoids, which have potential anti-viral and cytotoxic activities $[33,38]$. In fact, those flavonoids and phenolics were found to be responsible for their anti-inflammatory, anti-ulcer and gastrointestinal activities. Monoterpenoids and iridoids are also other important secondary metabolites of Sideritis species, former ones were found in their essential oils, mostly studied by Baser group [9,39]. Its leaves are consumed as tea, called mountain tea, particularly called as dağ çayı or Kemer çayı in the region including South-West Aegean and Mediteranean area of Turkey. To prepare a tea from a Sideritis species (namely Sideritis congesta, S. arguta, S. argyrea, S. libanotica subsp. linearis, S. pisidica and S. perfoliata), the dried leaves and spikes and/or heads are left as one or two spikes in a cup of boiled water for 2-3 min until appearance of nice yellow color with a pleasant aroma.

There are few previous studies on S. lycia. While one of them was on its flavonoid constituents, the others were on its essential oil analysis, both carried out by Ezer et al. [40]. Separately, a study was released on isolation of polyphenolic compounds from S. lycia with their anti-inflammatory activity $[41,42]$. A very recent study also reported phenolic compounds and antioxidant activity of S. lycia and S. libanotica subsp. linearis from natural and cultivated plant materials [43]. However, there is no report on isolation and structure elucidation studies on S. lycia diterpenoids.

In this study, an endemic Sideritis species S. lycia Boiss. et Heldr. apud Bentham, grown in Antalya region, collected at Kemer was investigated for its diterpenoids. Isolation and structure elucidation of the diterpenoids, based on NMR and mass spectral analyses, along with antiviral, cytotoxic and insecticidal activities are reported.

\section{Materials and Methods}

\subsection{General Experimental Procedures}

The spectra were recorded on the following instruments; NMR: ${ }^{1} \mathrm{H}-$ and ${ }^{13} \mathrm{C}-\mathrm{NMRs}$ were recorded on Varian $600 \mathrm{MHz}$ and $150 \mathrm{MHz}$, respectively, in $\mathrm{CDCl}_{3}$. For MS, VG ZabSpec High Resolution Mass Spectrometer and Bruker Daltonics microTOF-Q instruments were applied. Silica-gel 60 and Kieselgel $60 \mathrm{~F}_{254}$ (E.Merck) were used for column chromatography and prepared (TLC) plates, respectively. 


\subsection{Plant Material}

The aerial parts of S. lycia Boiss. et Heldr. apud Bentham were collected in Kemer (Antalya), Turkey (by Turgut Kilic) in June 2010, and the species was identified by Prof. Dr. K.H.C. Baser (Eskisehir). A voucher specimen was deposited in the Herbarium of the Faculty of Pharmacy, Anadolu University (ESSE 10143).

\subsection{Extraction and Isolation}

Dried and powdered aerial parts of $S$. lycia $(1.5 \mathrm{~kg})$ were extracted with hexane and acetone successively to yield $25 \mathrm{~g}$ and $30.2 \mathrm{~g}$ of the extracts, respectively. After checking them on TLC plates, the acetone extract appeared to be rich in diterpenoids. A small part of the acetone extract was separated for the activity tests, the remaining part was lyophilized and kept in deep-freeze. This part ( $30 \mathrm{~g})$ was then dissolved in a minimum amount of acetone, and some silica gel powder was added into a porcelain mortar and gently blended using a pestle, to obtain a homogeneous mixture at room temperature. The dried mixture was then added to the top of a silica gel column $(5 \mathrm{~cm} \times 80 \mathrm{~cm})$ chromatogtaphy. The initial elution was performed using hexane, after which a gradient of $\mathrm{CH}_{2} \mathrm{Cl}_{2}$ was added up to $100 \%$, which was followed by additions of acetone and then $\mathrm{MeOH}$. The fractions 29-31 were combined and subjected to a silica gel column chromatography $(2 \mathrm{~cm} \mathrm{x} 40 \mathrm{~cm})$, eluting with $\mathrm{CH}_{2} \mathrm{Cl}_{2}$ : acetone (9:1) solvent system. Similar fractions were combined to afford five main fractions (A-F). While the fraction $\mathrm{B}$ afforded 1 (4.88 g), which was the main compound of the acetone extract, fraction $\mathrm{C}$ gave 2 $\left(\mathrm{CH}_{2} \mathrm{Cl}_{2}\right.$ :acetone (80:20), $\left.53 \mathrm{mg}\right), 5\left(\mathrm{CH}_{2} \mathrm{Cl}_{2}\right.$ :acetone (80:20), $\left.25 \mathrm{mg}\right)$ and $\mathbf{6}\left(\mathrm{CH}_{2} \mathrm{Cl}_{2}\right.$ : acetone (85:15), $32 \mathrm{mg})$. The fraction D yielded $7\left(\mathrm{CH}_{2} \mathrm{Cl}_{2}\right.$ :acetone (80:20), $\left.8 \mathrm{mg}\right), \mathbf{3}\left(\mathrm{CH}_{2} \mathrm{Cl}_{2}\right.$ :acetone (90:10), $\left.73 \mathrm{mg}\right), 4$ $\left(\mathrm{CH}_{2} \mathrm{Cl}_{2}\right.$ :acetone (80:20),18 $\left.\mathrm{mg}\right)$ and $\mathbf{8}\left(\mathrm{CH}_{2} \mathrm{Cl}_{2}\right.$ : acetone (80:20), $\left.22 \mathrm{mg}\right)$.

\subsection{Antiviral Activity Assays}

\subsubsection{Sample Preparation}

All the samples were first dissolved in dimethylsulfoxide (DMSO) and tested at different concentrations according to Eagle's minimum essential medium (EMEM).

\subsubsection{Cell Culture and Virus (Cell Viability Assay)}

Vero cells are the normal African green monkey kidney epithelial cell lines which were grown and maintained in Eagle's minimum essential medium (EMEM) with Earle's saline, supplemented with an antibiotic-antimycotic mixture [penicillin $(100 \mathrm{U} / \mathrm{mL})$, streptomycin $(100 \mu \mathrm{g} / \mathrm{mL})$, amphotericin B $(0.25 \mu \mathrm{g} / \mathrm{mL})]$ and $10 \%$ fetal calf serum. The cells were kept in a humidified atmosphere containing $5 \%$ $\mathrm{CO}_{2}$ at $37{ }^{\circ} \mathrm{C}$. The Greer strain of human parainfluenza virus type 2 (HPIV-2) was used in all experiments and maintained in Vero cells. Approximately $10^{5}$ plaque forming units (p.f.u.) of virus in a minimal medium were allowed to be absorbed by Vero cells with a gentle rocking of the tissue culture flask every $10 \mathrm{~min}$ within $90 \mathrm{~min}$. The solution containing the virus was then removed, and a freshly prepared media, EMEM, containing $2 \%$ fetal calf serum, was added. The infected cells were allowed to grow until the cytopathic effect was completely obtained (usually in 48-72 h). The supernatant was removed, quickly frozen and stored at $-80{ }^{\circ} \mathrm{C}$ until it was used. The infectivity was determined by plaque assay on Vero cell monolayers, and expressed as plaque assay on Vero cell monolayers as a plaque forming unit per milliliter (p.f.u./mL).

\subsubsection{Cytotoxicity Assay}

The cytotoxicity assays were performed according to the micro culture MTT method [44,45]. The cells were harvested $\left(4.5-5.0 \times 10^{4}\right.$ cells/well $)$ and inoculated in 24 well microtiter plates. They were washed with phosphate buffered saline (PBS), and the cultured cells were then inoculated with and 
without the samples to be investigated. The final concentration of DMSO did not exceed $0.2 \%(\mathrm{v} / \mathrm{v})$, which is the concentration with no effect on cell replication. After $72 \mathrm{~h}$ incubation, the medium was aspirated. $150 \mu \mathrm{L}$ of MTT solution ( $5 \mathrm{mg} / \mathrm{mL}$, in PBS, $\mathrm{pH}$ 7.2) was then added to each well, and the plates were incubated for $4 \mathrm{~h}$ at $37^{\circ} \mathrm{C}$, after which $800 \mu \mathrm{L}$ of DMSO was added to each well of the plates, followed by gentle shaking for $15 \mathrm{~min}$ to solubilize the formazan dye. Absorbance was measured at $540 \mathrm{~nm}$ using a photometer, and the surviving compounds (or extract) were calculated.

\subsubsection{Plaque Assay}

Confluent monolayer cultures of Vero cells in a $60 \mathrm{~mm}$ plastic dish were washed twice with Dulbecco's phosphate buffer saline (PBS) and exposed to HPIV-2. After adsorption for $90 \mathrm{~min}$ at $37^{\circ} \mathrm{C}$, the cells were washed twice with PBS, overlaid with EMEM, containing 0.9\% agarose, and the acetone extract of S. lycia and its pure diterpenoids were prepared at four different concentrations. The cultures were incubated at $37{ }^{\circ} \mathrm{C}$ for 3-4 days. At the end of this period, the cell monolayers were fixed in the formol-saline for $15 \mathrm{~min}$ and stained with amido black [45,46]. Concentration of each sample, which was required to inhibit the virus plaque number, was estimated.

\subsubsection{Evaluation of Cytotoxic Activity Against Several Cancer Cell Lines}

The compounds $\mathbf{1}$ - 3, 7 and $\mathbf{8}$ were evaluated with cultured KB (human epidermoid carcinoma), P-388 (mouse leukemia), COL-2 (human colon cancer), hTERT RPE (human retinal pigmented epithelial cancer), LU1 (human lung cancer), LNCaP (hormone-dependent human prostate cancer) and A2780 (human ovarian cancer) cell lines [47-49].

\section{Results and Discussion}

Fractionation and isolation studies from the acetone extract of $S$. lycia were performed on a silica gel CC (column chromatography) and purified by prep. TLC to afford 8 diterpenoids. Their structure elucidation was made based on 1D and 2D NMR and mass spectroscopic techniques which were identified as ent-kaurane diterpenoids; linearol (1), sidol (2), 7-epi-candicandiol (3), foliol (4) isolinearol (5), isosidol (6), siderol (7), and sideridiol (8) (Figure 1 and Table 1). Linearol (1) was obtained as the main compound of the acetone extract of $S$. lycia in a fairly high yield $(0.33 \%$, based on dried plant material weight). Some of the other Anatolian Sideritis species also yielded linearol in high yield, but, none of these species has afforded yet such high linearol percentage. These are $S$. athoa $(0.1 \%)$ [22], S. argyrea (0.13\%) [23] and S. sipylea (0.03\%) [24], obtained in our previous studies. Thus, $S$. lycia should be considered as a rich resource of linearol. In terms of diterpenic compounds, Sideritis species are fairly rich compared to the most of the other genera of Lamiaceae family plants, such as Salvia species. The percentage of the other diterpenoids, isolated along with linearol from the same extract of S. lycia, are as follows: sidol (2) (0.035\%), 7-epi-candicandiol (3) $(0.048 \%)$, foliol (4) $(0.012 \%)$, isolinearol (5) $(0.016 \%)$, isosidol (6) $(0.021 \%)$, siderol (7) $(0.005 \%)$, and sideridiol (8) $(0.014 \%)$. Linearol (1) [50,51], sidol (2) [52], 7-epi-candicandiol (3) [51], foliol (4) [51,53], isolinearol (5) [54], isosidol (6) [52,55], siderol (7) [56] and sideridiol (8) [55] were characterized by using 1D and 2D NMR techniques along with mass spectroscopy.

Concentrations of both inhibition of virus plaque formation $\left(\mathrm{as}_{50}\right)$ and reduced viability of Vero cells $\left(\right.$ as $\left.\mathrm{CD}_{50}\right)$ of the acetone extract and the three diterpenoids of $S$. lycia were investigated. None of them was found to be cytotoxic up to $0.1 \mu \mathrm{g} / \mathrm{mL}$, indicating that they could be promising antiviral agents, particularly isosidol and linearol. Furthermore, cytotoxicity of the isolated five ent-kaurane diterpenoids were screened against seven different cancer cell lines; only 7-epi-candicandiol showed meaningful results.

\subsection{In vitro Antiviral Activity}

Antiviral potency of the acetone extract was investigated at four concentrations, i.e. $0.1,0.5,1.0$ and $10.0 \mu \mathrm{g} / \mathrm{mL}$. Fifty percent effective dose required to inhibit virus plaque formation (Table 1 ). 


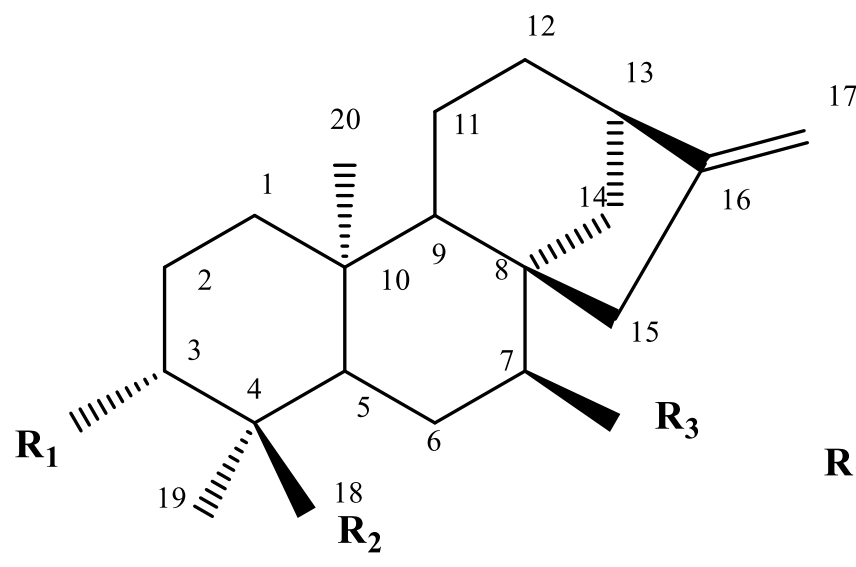

$\begin{array}{lccc} & \mathbf{R}_{\mathbf{1}} & \mathbf{R}_{\mathbf{2}} & \mathbf{\mathbf { R } _ { 3 }} \\ \mathbf{1} & \mathrm{OH} & \mathrm{CH}_{2} \mathrm{OAc} & \mathrm{OH} \\ \mathbf{2} & \mathrm{OAc} & \mathrm{CH}_{2} \mathrm{OH} & \mathrm{OH} \\ \mathbf{3} & \mathrm{H} & \mathrm{CH}_{2} \mathrm{OH} & \mathrm{OH} \\ \mathbf{4} & \mathrm{OH} & \mathrm{CH}_{2} \mathrm{OH} & \mathrm{OH}\end{array}$

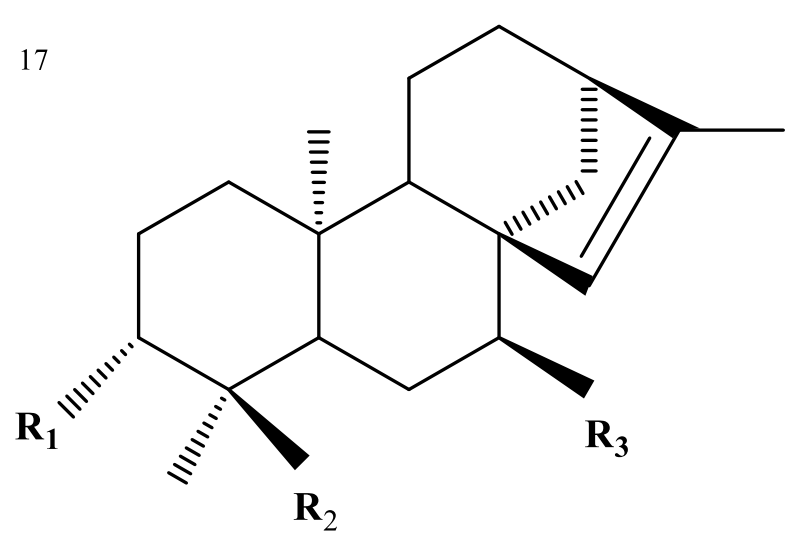

$\begin{array}{lccc} & \mathbf{R}_{\mathbf{1}} & \mathbf{R}_{\mathbf{2}} & \mathbf{\mathbf { R } _ { 3 }} \\ \mathbf{5} & \mathrm{OH} & \mathrm{CH}_{2} \mathrm{OH} & \mathrm{OH} \\ \mathbf{6} & \mathrm{OAc} & \mathrm{CH}_{2} \mathrm{OH} & \mathrm{OH} \\ \mathbf{7} & \mathrm{H} & \mathrm{OH} & \mathrm{OAc} \\ \mathbf{8} & \mathrm{OH} & \mathrm{OH} & \mathrm{OH}\end{array}$

Figure 1. Structures of the isolated compounds (1-8)

The $\mathrm{CD}_{50}$ values of the tested compounds, linearol (1), sidol (2) and isosidol (6), and the acetone extract for the viability of Vero cells were determined as 29.32, 14.64, 27.27 and $2.91 \mu \mathrm{g} / \mathrm{mL}$, respectively. Although acetone extract of $S$. lycia displayed the best $\mathrm{CD}_{50}$ and $\mathrm{ED}_{50}$ values, the most active compound was found to be isosidol (Table 2). Antiviral index (AI) values of linearol and isosidol were close to each other. However, sidol showed almost no plaque inhibition effect, thus, it was determined to be inactive.

Table 1. Antiviral potency of ent-kaurenes and acetone extract of S. lycia on HPIV-2 in Vero Cells

\begin{tabular}{llll}
\hline Compound & $\mathrm{ED}_{50}(\mu \mathrm{g} / \mathrm{mL})^{\mathrm{a}}$ & $\mathrm{CD}_{50}(\mu \mathrm{g} / \mathrm{mL})^{\mathrm{b}}$ & $\mathrm{AI}^{\mathrm{c}}$ \\
\hline Linearol (1) & $12.72 \pm 2.80^{\mathrm{e}}$ & $29.32 \pm 3.32^{\mathrm{e}}$ & 2.31 \\
Sidol (2) & $\mathrm{NA}^{\mathrm{d}}$ & $27.27 \pm 3.10$ & $\mathrm{NA}$ \\
Isosidol (6) & $7.27 \pm 1.59$ & $14.64 \pm 1.50$ & 2.01 \\
S. lycia (Acetone Extract) & $1.13 \pm 0.25$ & $2.91 \pm 1.20$ & 2.58 \\
\hline
\end{tabular}

${ }^{a}$ Fifty -percent effective dose, or concentration required to inhibit virus plaque formation by $50 \%$.

${ }^{\mathrm{b}}$ The concentration of tested compounds/extract which reduced viability of Vero cells by $50 \%$.

${ }^{\mathrm{c}}$ Antiviral index $\left(\mathrm{CD}_{50} / \mathrm{ED}_{50}\right)$

${ }^{\mathrm{d}} \mathrm{NA}$ : Not Active

${ }^{\mathrm{e}}$ Values $\mathrm{ED}_{50}$ and $\mathrm{CD}_{50}$ are averages and standard deviations for three independent experiments

\subsection{Cytotoxic Activities Against a Series Cancer Cell Lines}

Linearol (1), sidol (2), 7-epi-candicandiol (3) siderol (7) and sideridiol (8) of S. lycia were evaluated for their cytotoxicity against KB, P-388, COL-2, hTERT RPE (human retinal pigmented epithelial cancer), LU1, LNCaP and A2780 cell lines (Table 2). While 7-epi-candicandiol (7) was found to be active in almost all the tested cell lines, including KB $(13.3 \mu \mathrm{g} / \mathrm{mL}), \mathrm{COL}-2(11.8 \mu \mathrm{g} / \mathrm{mL}), \mathrm{LU} 1$ $(17.9 \mu \mathrm{g} / \mathrm{mL}), \mathrm{LNCaP}(14.9 \mu \mathrm{g} / \mathrm{mL})$ and A2780 $(9.0 \mu \mathrm{g} / \mathrm{mL})$ (Table 3), compound 2 (sidol) showed moderate activity against only A2780 at $15.6 \mu \mathrm{g} / \mathrm{mL}$. The other diterpenoids did not display a satisfactory activity on the tested cancer cell lines (Table 2). 
Table 2. Cytotoxic activity results of ent-kaurane diterpenoids $(\mathbf{1 , 2 - 8})$ against a panel of cancer cell lines ${ }^{\mathrm{a}}$

\begin{tabular}{lccccccc}
\hline Compound & KB & P-388 & COL-2 & $\begin{array}{c}\text { hTERT } \\
\text { RPE }\end{array}$ & LU 1 & LNCaP & A2780 \\
\hline 7-Epicandicandiol (3) & 13.3 & $>20$ & 11.8 & NT & 17.9 & 14.9 & 9.0 \\
Sidol (2) & $>20$ & $>20$ & $>20$ & $>20$ & $>20$ & $>20$ & 15.6 \\
Siderol (7) & $>20$ & $>20$ & $>20$ & $>20$ & $>20$ & $>20$ & $>20$ \\
Sideridiol (8) & $>20$ & $>20$ & $>20$ & $>20$ & $>20$ & $>20$ & $>20$ \\
Linearol (1) & $\mathrm{NT}$ & $\mathrm{NT}$ & $\mathrm{NT}$ & $\mathrm{NT}$ & $\mathrm{NT}$ & $\mathrm{NT}$ & $>20$ \\
$\begin{array}{l}\text { Ellipticine } \\
\text { (positive control) }\end{array}$ & 0.02 & 0.3 & 0.04 & 0.3 & 0.1 & 0.8 & - \\
\hline
\end{tabular}

${ }^{a}$ Compounds were initially tested at a concentration of $20 \mu \mathrm{g} / \mathrm{mL}$, and followed by dose-response studies, as required to the yield $\mathrm{ED}_{50}$ values $(\mu \mathrm{g} / \mathrm{mL})$.

\subsection{Insecticidal Activity}

The use of synthetic insecticides in agriculture as pest control agents to increase the harvest and protect the stored products may involve serious health hazards for mammals. These insecticides are often associated with residuals that are hazardous for consumers and environment [56]. Particularly, the used chemicals in fighting these stored pests contain many dangers for human and animal health across the world [56-57]. The risk of developing insect resistance and the high cost-benefit ratio of synthetic pesticides channeled research towards alternative insecticides. The number of confirmed insect resistant species to synthetic pesticides has been continuing to rise [56,57]. Therefore, there is an urgent need to develop safer, environmentally friendly and efficient alternative to replace synthetic pesticides. As the natural products are well known to have a range of useful biological properties against insect pests, the acetone extract of S. lycia was tested against Tetranychus urticae, Bemicia tabaci, Sitophilus granaries and Lasioderma serricorne for the insecticidal activity profile. The P values' test was conducted for the statistical significance of dose and time against the above insects.

In the contact toxicity assay, $S$. lycia extract showed the highest toxicity against Bemicia tabaci with $63 \%(250 \mu \mathrm{L})$ and $81 \%(750 \mu \mathrm{L})$ mortalities at the end of $120 \mathrm{~h}$. The extract also showed activity against Tetranychus urticae with $63 \%$ and Sitophilus granarius $47 \%(750 \mu \mathrm{L})$ at the end of $120 \mathrm{~h}$. The lowest toxicity was observed against Lasioderma serricorne with $15 \%$ mortality (Figure 2). The toxicity of the acetone extract of S. lycia was significantly increased with time until up to $120 \mathrm{~h}$ (Figure 2).

Topical application of the S.lycia extract displayed a different toxicity compare with contact toxicity assay. The best insecticidal activity was observed against Lasioderma serricorne instead of Bemicia tabaci, with a mortality rate of $82 \%(2 \mu \mathrm{L})$ after $120 \mathrm{~h}$. Toxicity of acetone extract was determined to have 68, 58 and 39\% mortality against S. granarius, Bemicia tabaci and Tetranychus urticae, respectively (Figure 3 ).

The main compound linearol (1), which is the $11.3 \%$ of the total acetone extract of S. lycia, was also tested against above organisms. By the contact toxicity assay, the mortality percentages of linearol (1) were determined as 80, 75, 70 and $40 \%(750 \mu \mathrm{L})$ against Bemicia tabaci, Lasioderma serricorne, Tetranychus urticia and Sitophilus granarius, respectively (Figure 3), which are matching with our previous result [29]. 7-Epi-candicandiol (3) from S. lycia was previously reported by our group, therefore, we do not report herein once more [36]. 
Contact toxicity of S.lycia $(24 \mathrm{~h})$

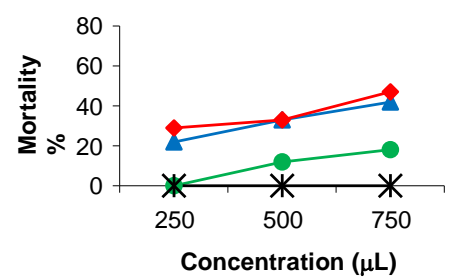

Contact toxicity of S.lycia (96h)

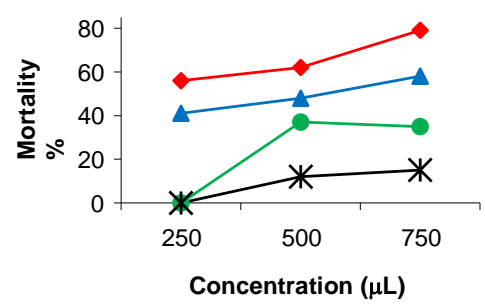

Contact toxicity of linearol (1) (24h)

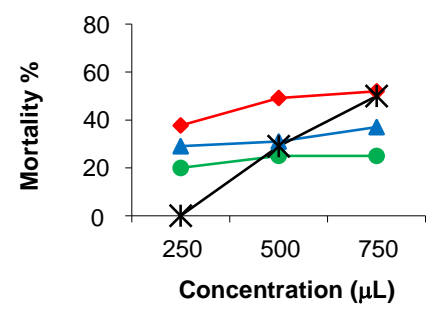

Contact toxicity of linearol (1) (96h)

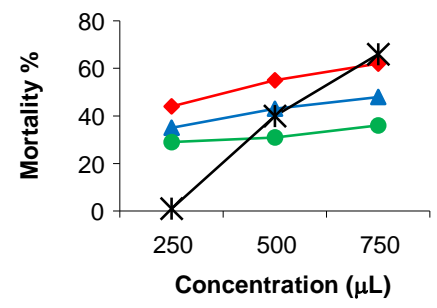

Contact toxicity of S.lycia $(48 \mathrm{~h})$

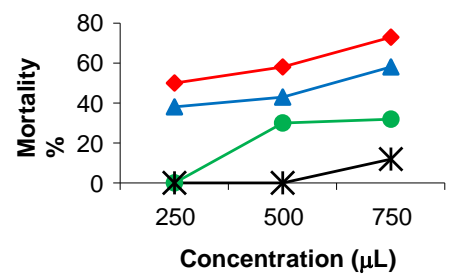

Contact toxicity of S.lycia $(120 \mathrm{~h})$

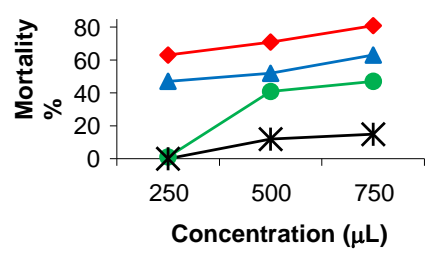

$\begin{array}{ll}\longrightarrow \text { Tetranychus urticae } & - \text { Bemicia tabaci } \\ - \text { - Sitophilus granarius } & \rightarrow \text { Lasioderma serricorne }\end{array}$

Contact toxicity of linearol (1) (48h)

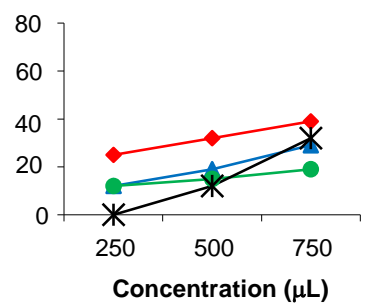

Contact toxicity of linearol (1) (120h)



Concentration $(\mu \mathrm{L})$

Figure 2. Percent mortality of insects for all doses and periods of the acetone extract of S.lycia and linearol (1) with contact toxicity assay 
Topical toxicity of S.lycia $(24 \mathrm{~h})$

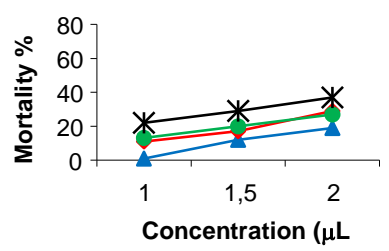

Topical toxicity of S.lycia (96h)

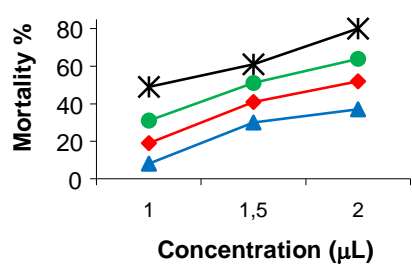

Topical toxicity of linearol (1) (24 h)

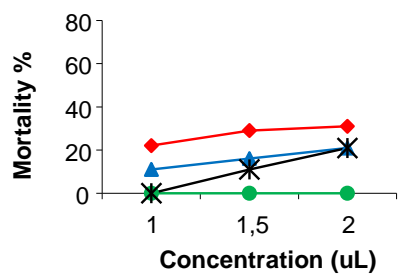

Topical toxicity of linearol (1) (96h)

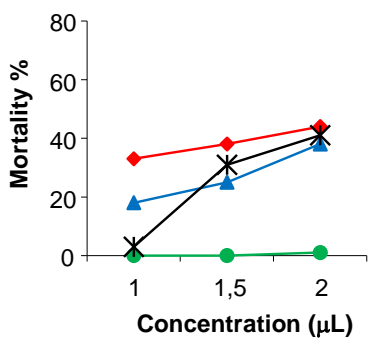

Topical toxicity of S.lycia $(48 \mathrm{~h})$

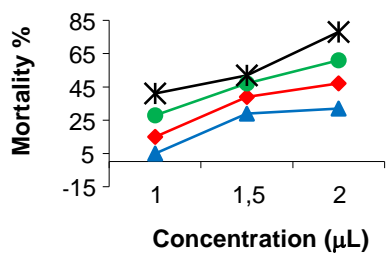

Topical toxicity of S.lycia $(120 \mathrm{~h})$

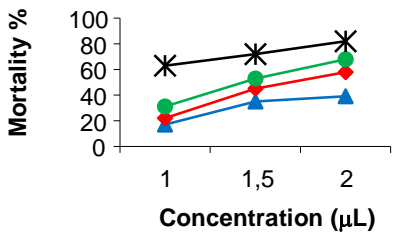

- Tetranychus urticae $-\bullet-$ Bemicia tabaci - Sitophilus granarius $\rightarrow$ * Lasioderma serricorne

Topical toxicity of linearol (1) (48 h)

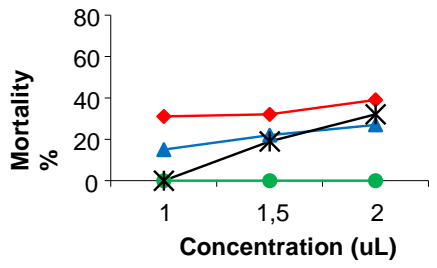

Topical toxicity of linearol (1) (120 h)

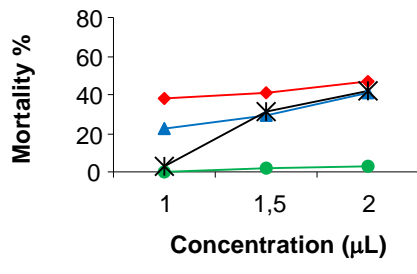

Tetranychus urticae $-\longrightarrow$ Bemicia tabaci Sitophilus granarius $\rightarrow$ * Lasioderma serricorne

Figure 3. Percent mortality of insects for all doses and periods of the acetone extract of S.lycia and linearol (1) with topical application 
Diterpenoids enriched acetone extract of S. lycia and main components of linearol (1) had a statistically significant effect on mortality of Tetranychus urticae, Bemicia tabaci, Sitophilus granaries and Lasioderma serricorne ( $\mathrm{P}<0.01$ ) at 95\% confidence level (Table S1). Based on these results, Linearol (1) should be concluded as one of the most active ingredients of S. lycia. Sideritis plants. containing Linearol and related kaurene diterpenoids ean could be potential source to be used in sustainable pest management $[29,36]$.

In order to determine whether there is statistically significant difference in toxicity between insecticidal activity and time, Statgraph software was used for the ANOVA test (Table S1 and Table S2), which indicated a significant difference at $P<0.01$.

\subsection{Structure Elucidation}

The isolated compounds were identified to be known ent-kauranes linearol (1), sidol (2), 7 epi-candicandiol (3), foliol (4) isolinearol (5), isosidol (6), siderol (7) and sideridiol (8), using 1D and 2D-NMR and mass spectroscopic techniques as well as comparison with authentic samples. The main diterpenoids of Sideritis species have ent-kaurane skeleton possessing four rings. The characteristic signals in the ${ }^{1} \mathrm{H}$ NMR spectrum for ent-kaurane skeleton are due to the presence of maximum 4 methyl groups and, in some cases, two-three methyl groups, namely, C-18 or C-17 might be substituted with hydroxyl group. In some ent-kauranes, C-18 methyl group may have an acetate substituent, Me-17 might be converted into a methylene group (as seen in compounds 1, 2, 3 and 4) or its isomer having a vinylic methyl group (as seen in compounds 5, 6, $\mathbf{7}$ and 8). The most preferred location for the hydroxyl or acetyl groups in the ent-kauranes is C-7, followed by C-3. The most characteristic signal in all ent-kaurane diterpenoids is the appearance of $\mathrm{C}-13$ proton signal, observed at about $2.3 \mathrm{ppm}$ with a characteristic multiplicity. Generally, it appears like a broadened triplet rather than a multiplet due to the vicinity of two methylene pairs at C-12 and C-14 to C-13 atom. Although in some cases, some substituents may replace those $\mathrm{C}$ atoms, we only observed a few cases, such as in athonolone [20]. Since all the isolated diterpenoids had the known ent-kaurane structures in this study, their detailed structure elucidation is not given herein (see ${ }^{3} \mathrm{C}$ NMR data in Table 3 ).

Linearol (1) ${ }^{1} \mathrm{H}-\mathrm{NMR}\left(600 \mathrm{MHz}, \mathrm{CDCl}_{3}\right): \delta 4.82(1 \mathrm{H}, \mathrm{br} \mathrm{s}, \mathrm{H}-17 \mathrm{a}), 4.79(1 \mathrm{H}, \mathrm{br} \mathrm{s}, \mathrm{H}-17 \mathrm{~b}), 4.07(1 \mathrm{H}$, d, $J=11.5 \mathrm{~Hz}, \mathrm{H}-18 \mathrm{a}), 3.99(1 \mathrm{H}, \mathrm{d}, J=11.5 \mathrm{~Hz}, \mathrm{H}-18 \mathrm{~b}), 3.61(1 \mathrm{H}, \mathrm{t}, J=2.5 \mathrm{~Hz}, \mathrm{H}-7 \alpha), 3.53(1 \mathrm{H}, \mathrm{dd}$, $J=7.5 \mathrm{~Hz}$ and $9 \mathrm{~Hz}, \mathrm{H}-3 \beta) 2.72(1 \mathrm{H}, \mathrm{m}, \mathrm{H}-13), 2.09\left(3 \mathrm{H}, \mathrm{s}, \mathrm{O}-\mathrm{COCH}_{3}\right), 1.05(3 \mathrm{H}, \mathrm{s}, \mathrm{Me}-20), 0.77$ (3H, s, Me-19). ${ }^{13} \mathrm{C}$ NMR (150 MHz, $\left.\mathrm{CDCl}_{3}\right)$ (see Table 3). EI-MS: $(\mathrm{m} / \mathrm{z}) 362.2(14 \%)[\mathrm{M}]^{+}$for $\left(\mathrm{C}_{22} \mathrm{H}_{34} \mathrm{O}_{4}\right), 344.2(40 \%)\left[\mathrm{M}-\mathrm{H}_{2} \mathrm{O}\right]^{+}, 326.2(98 \%)\left[\mathrm{M}-2 \mathrm{H}_{2} \mathrm{O}\right]^{+}$.

7-Epi-candicandiol (3): ${ }^{1} \mathrm{H}-\mathrm{NMR}\left(600 \mathrm{MHz}, \mathrm{CDCl}_{3}\right): \delta 4.80\left(2 \mathrm{H}\right.$, brs, $\left.\mathrm{H}_{2}-17\right), 3.66(1 \mathrm{H}, \mathrm{t}, J=2.2 \mathrm{~Hz}$, H-7), $3.47(1 \mathrm{H}, \mathrm{d}, J=12 \mathrm{~Hz}, \mathrm{H}-18 \mathrm{a}), 2.92(1 \mathrm{H}, \mathrm{d}, J=12 \mathrm{~Hz}, \mathrm{H}-18 \mathrm{~b}), 2.69(1 \mathrm{H}, \mathrm{m}, \mathrm{H}-13), 1.05$ (3H, s, Me-20), 0.69 (3H, s, Me-19). ${ }^{13} \mathrm{C}$ NMR (150 MHz, $\left.\mathrm{CDCl}_{3}\right)$ (see Table 1). EI-MS: $(\mathrm{m} / \mathrm{z}) 304.0(3 \%)$ $[\mathrm{M}]^{+}$for $\left(\mathrm{C}_{20} \mathrm{H}_{32} \mathrm{O}_{2}\right), 286.2(47 \%)\left[\mathrm{M}-\mathrm{H}_{2} \mathrm{O}\right]^{+}, 271.0(18 \%)\left[\mathrm{M}-\mathrm{H}_{2} \mathrm{O}-\mathrm{CH}_{3}\right]^{+}, 268.0(99 \%)\left[\mathrm{M}-2 \mathrm{H}_{2} \mathrm{O}\right]^{+}$.

Sidol (2): ${ }^{1} \mathrm{H}-\mathrm{NMR}\left(600 \mathrm{MHz}, \mathrm{CDCl}_{3}\right): \delta 4.90(1 \mathrm{H}, \mathrm{dd}, J=5$ and $11 \mathrm{~Hz}, \mathrm{H}-3), 4.80-4.82\left(2 \mathrm{H}\right.$, brs, $\mathrm{H}_{2}-$ 17), $3.62(1 \mathrm{H}, \mathrm{t}, J=3 \mathrm{~Hz}, \mathrm{H}-7), 3.32(1 \mathrm{H}, \mathrm{d}, J=12 \mathrm{~Hz}, \mathrm{H}-18 \mathrm{a}), 2.97(1 \mathrm{H}, \mathrm{d}, J=12 \mathrm{~Hz}, \mathrm{H}-18 \mathrm{~b}), 2.68$ $(1 \mathrm{H}, \mathrm{m}, \mathrm{H}-13), 2.08\left(3 \mathrm{H}, \mathrm{s}, \mathrm{O}-\mathrm{COCH}_{3}\right), 1.08(3 \mathrm{H}, \mathrm{s}, \mathrm{Me}-20), 0.68(3 \mathrm{H}, \mathrm{s}, \mathrm{Me}-19) .{ }^{13} \mathrm{C}$ NMR $(150$ $\mathrm{MHz}, \mathrm{CDCl}_{3}$ ) (see Table 1). EI-MS: $(\mathrm{m} / \mathrm{z}) 362.3(4 \%)[\mathrm{M}]^{+}$for $\left(\mathrm{C}_{22} \mathrm{H}_{34} \mathrm{O}_{4}\right), 332.3(6 \%)\left[\mathrm{M}-\mathrm{H}_{2} \mathrm{O}\right]^{+}$, $326.3(8 \%)\left[\mathrm{M}-\mathrm{H}_{2} \mathrm{O}\right]^{+}, 314.2\left[\mathrm{M}-\mathrm{H}_{2} \mathrm{O}-2 \mathrm{CH}_{3}\right]^{+}(10 \%), 302.0(4 \%)\left[\mathrm{M}-\mathrm{CH}_{3} \mathrm{COOH}\right]^{+}$.

Foliol (4): ${ }^{1} \mathrm{H}-\mathrm{NMR}\left(600 \mathrm{MHz}, \mathrm{CDCl}_{3}\right): \delta 4.84(\mathrm{H}-17 \mathrm{a}$ br s), $4.72(\mathrm{H}-17 \mathrm{br} \mathrm{s}), 3.67(1 \mathrm{H}, \mathrm{dd}, J=6.0$ and $11 \mathrm{~Hz}, \mathrm{H}-3), 3.47(1 \mathrm{H}, \mathrm{d}, J=12 \mathrm{~Hz}, \mathrm{H}-18 \mathrm{a}), 3.63(\mathrm{H}-7, \mathrm{t}, J=2.5 \mathrm{~Hz}), 3.40(1 \mathrm{H}, \mathrm{d}, J=12.0 \mathrm{~Hz}, \mathrm{H}-$ 18b), $2.69(\mathrm{H}-13, \mathrm{~m}), 0.78(\mathrm{H}-19, \mathrm{~s}), 1.06(\mathrm{H}-20, \mathrm{~s}) .{ }^{13} \mathrm{C}$ NMR $\left(150 \mathrm{MHz}, \mathrm{CDCl}_{3}\right)$ (see Table 1). EIMS: $(\mathrm{m} / z) 320.3(3 \%)[\mathrm{M}]^{+}$for $\left(\mathrm{C}_{20} \mathrm{H}_{32} \mathrm{O}_{3}\right), 302.3(49 \%)\left[\mathrm{M}-\mathrm{H}_{2} \mathrm{O}\right]^{+}, 294.3(50 \%)\left[\mathrm{M}-2 \mathrm{H}_{2} \mathrm{O}\right]^{+}, 272.3$ (98\%) $\left[\mathrm{M}-\mathrm{H}_{2} \mathrm{O}-\mathrm{CH}_{2} \mathrm{OH}\right]^{+}$. 
Table 3. ${ }^{13} \mathrm{C}-\mathrm{NMR}$ data of the isolated ent-kaurenes (1-8) from S. lycia

\begin{tabular}{ccccccccc}
\hline Position & $\mathbf{1}$ & $\mathbf{2}$ & $\mathbf{3}$ & $\mathbf{4}$ & $\mathbf{5}$ & $\mathbf{6}$ & $\mathbf{7}$ & $\mathbf{8}$ \\
\hline 1 & 38.2 & 38.4 & 39.7 & 39.0 & 38.4 & 38.3 & 44.5 & 42.0 \\
2 & 27.6 & 23.4 & 17.9 & 28.1 & 26.4 & 23.4 & 18.3 & 18.4 \\
3 & 72.2 & 74.5 & 38.3 & 74.0 & 72.3 & 74.6 & 35.2 & 35.2 \\
4 & 38.8 & 43.6 & 37.7 & 39.3 & 41.9 & 38.7 & 36.9 & 37.1 \\
5 & 38.0 & 37.4 & 37.1 & 42.1 & 37.8 & 37.0 & 44.5 & 44.6 \\
6 & 26.4 & 26.5 & 26.6 & 21.6 & 26.7 & 26.0 & 23.5 & 25.0 \\
7 & 76.8 & 76.9 & 77.1 & 76.5 & 74.9 & 74.9 & 78.3 & 75.4 \\
8 & 48.2 & 50.2 & 48.2 & 48.7 & 53.1 & 53.2 & 51.8 & 51.8 \\
9 & 50.2 & 50.2 & 50.4 & 50.6 & 43.9 & 44.1 & 44.8 & 44.8 \\
10 & 38.2 & 38.1 & 39.6 & 39.0 & 39.1 & 41.7 & 39.2 & 39.2 \\
11 & 17.8 & 17.4 & 17.9 & 18.2 & 18.4 & 18.5 & 17.9 & 18.0 \\
12 & 33.5 & 33.6 & 33.5 & 33.9 & 24.8 & 24.9 & 24.8 & 26.3 \\
13 & 43.8 & 44.1 & 43.7 & 44.2 & 44.6 & 44.7 & 39.8 & 44.2 \\
14 & 38.1 & 39.1 & 34.9 & 38.8 & 42.0 & 42.0 & 39.8 & 44.2 \\
15 & 44.6 & 44.8 & 45.2 & 46.1 & 130.3 & 130.0 & 129.8 & 129.7 \\
16 & 155.0 & 153.9 & 155.1 & 155.9 & 143.9 & 143.8 & 143.8 & 146.1 \\
17 & 103.6 & 103.6 & 103.4 & 103.4 & 15.4 & 15.4 & 15.4 & 15.5 \\
18 & 66.0 & 64.1 & 70.5 & 68.7 & 66.0 & 64.1 & 71.3 & 71.1 \\
19 & 11.9 & 12.8 & 17.9 & 12.8 & 11.8 & 12.7 & 17.4 & 17.7 \\
20 & 17.8 & 15.4 & 17.8 & 18.2 & 18.0 & 18.0 & 17.8 & 17.7 \\
$\mathrm{O}_{\mathrm{CO}}$ & 21.2 & 21.2 & & & 21.2 & 21.2 & 21.4 & \\
$\mathrm{O}_{3} \underline{\underline{C O C}} \mathrm{H}_{3}$ & 171.8 & 170.8 & & & 171.9 & 171.8 & 170.8 & \\
\hline
\end{tabular}

Isolinearol (5) ${ }^{1} \mathrm{H}$ NMR: $\left(600 \mathrm{MHz}, \mathrm{CDCl}_{3}\right): 5.45(1 \mathrm{H}, \mathrm{s}, \mathrm{H}-15), 4.01(1 \mathrm{H}, \mathrm{d}, J=11.0 \mathrm{~Hz}, \mathrm{H}-18 \mathrm{a})$, $3.92(1 \mathrm{H}, \mathrm{d}, J=11.0, \mathrm{H}-18 \mathrm{~b}), 3.58(1 \mathrm{H}, \mathrm{t}, J=2.5 \mathrm{~Hz}, \mathrm{H}-7), 3.46(1 \mathrm{H}, \mathrm{dd}, J=7.0$ and $11.0 \mathrm{~Hz}, \mathrm{H}-3)$, $2.32(1 \mathrm{H}, \mathrm{m}, \mathrm{H}-13), 2.04\left(3 \mathrm{H}, \mathrm{s},\left(\mathrm{O}-\mathrm{COCH}_{3}\right), 1.68(3 \mathrm{H}, \mathrm{d}, J=1.0 \mathrm{~Hz}, \mathrm{Me}-17), 1.01(3 \mathrm{H}, \mathrm{s}, \mathrm{Me}-20\right.$, s), $0.71(3 \mathrm{H}, \mathrm{s}, \mathrm{Me}-19) .{ }^{13} \mathrm{C}$ NMR $\left(150 \mathrm{MHz}, \mathrm{CDCl}_{3}\right)$ (see Table 1). EI- MS: $(\mathrm{m} / \mathrm{z}) 362.3(35 \%)[\mathrm{M}]^{+}$ for $\left(\mathrm{C}_{22} \mathrm{H}_{34} \mathrm{O}_{4}\right), 326.3(8 \%)\left[\mathrm{M}-2 \mathrm{H}_{2} 0\right]^{+}$.

Isosidol (6): ${ }^{1} \mathrm{H}$ NMR: $\left(600 \mathrm{MHz}, \mathrm{CDCl}_{3}\right): 5.50(1 \mathrm{H}, \mathrm{s}, \mathrm{H}-15), 4.87(1 \mathrm{H}, \mathrm{dd}, J=7.0$ and $11.0 \mathrm{~Hz}, \mathrm{H}-$ 3), $3.58(1 \mathrm{H}, \mathrm{t}, J=2.5 \mathrm{~Hz}, \mathrm{H}-7), 3.26$ (1H, d, $J=11.0, \mathrm{H} 18 \mathrm{a}), 2.93$ (1H, d, $J=11.0, \mathrm{H} 18 \mathrm{~b}), 2.31$ ( $1 \mathrm{H}$, m, H-13), $1.67(3 \mathrm{H}, \mathrm{d}, J=0.5 \mathrm{~Hz}, \mathrm{H}-17, \mathrm{~s}), 2.01\left(3 \mathrm{H}, \mathrm{s},\left(\mathrm{O}-\mathrm{COCH}_{3}\right), 1.02(3 \mathrm{H}, \mathrm{s}, \mathrm{Me}-20), 0.68\right.$ $(3 \mathrm{H}, \mathrm{s}, \mathrm{Me}-19) .{ }^{13} \mathrm{C}$ NMR $\left(150 \mathrm{MHz}, \mathrm{CDCl}_{3}\right)$ (see Table 1). EI-MS: $(\mathrm{m} / \mathrm{z}) 362.3(26 \%)[\mathrm{M}]^{+}$for $\left(\mathrm{C}_{22} \mathrm{H}_{34} \mathrm{O}_{4}\right), 314.2(7 \%)\left[\mathrm{M}-\mathrm{H}_{2} \mathrm{O}-2 \mathrm{CH}_{3}\right]^{+}, 300.2(14 \%)\left[\mathrm{M}-\mathrm{CH}_{3} \mathrm{COOH}\right]^{+}$.

Siderol (7): ${ }^{1} \mathrm{H}-\mathrm{NMR}\left(600 \mathrm{MHz}, \mathrm{CDCl}_{3}\right): \delta 5.25(1 \mathrm{H}, \mathrm{s}, \mathrm{H}-15), 4.60(1 \mathrm{H}, \mathrm{t}, J=2.5 \mathrm{~Hz}, \mathrm{H}-7), 2.98(1 \mathrm{H}$, $\mathrm{d}, J=11.5 \mathrm{~Hz}, \mathrm{H}-18 \mathrm{a}), 3.31(1 \mathrm{H}, \mathrm{d}, J=11.5 \mathrm{~Hz}, \mathrm{H}-18 \mathrm{~b}), 2.37(1 \mathrm{H}, \mathrm{m}, \mathrm{H}-13), 2.05\left(3 \mathrm{H}, \mathrm{s}, \mathrm{O}-\mathrm{COCH}_{3}\right)$, $1.69(3 \mathrm{H}, \mathrm{d}, J=0.5 \mathrm{~Hz}, \mathrm{Me}-17), 1.11(3 \mathrm{H}, \mathrm{s}, \mathrm{Me}-20), 0.67(3 \mathrm{H}, \mathrm{s}, \mathrm{Me}-19) .{ }^{13} \mathrm{C}$ NMR $(150 \mathrm{MHz}$, $\mathrm{CDCl}_{3}$ ) (see Table 1). EI- MS: $(\mathrm{m} / \mathrm{z}) 346.0(32 \%)[\mathrm{M}]^{+}$for $\left(\mathrm{C}_{22} \mathrm{H}_{34} \mathrm{O}_{3}\right), 315.0(3 \%)\left[\mathrm{M}-\mathrm{CH}_{2} \mathrm{OH}\right]^{+}$, $303.9(68 \%)[\mathrm{M}-44]^{+}, 287.0(76 \%)\left[\mathrm{M}-\mathrm{OCOCH}_{3}\right]^{+}, 268.1(76 \%)\left[\mathrm{M}-\mathrm{CH}_{3} \mathrm{COOH}-\mathrm{H}_{2} \mathrm{O}\right]^{+}$.

Sideridiol (8): ${ }^{1} \mathrm{H}-\mathrm{NMR}\left(600 \mathrm{MHz}, \mathrm{CDCl}_{3}\right): \delta 5.45(1 \mathrm{H}, \mathrm{brs}, \mathrm{H}-15), 3.61(1 \mathrm{H}, \mathrm{t}, J=2.5 \mathrm{~Hz}, \mathrm{H}-7), 3.47$ $(1 \mathrm{H}, \mathrm{d}, J=11.5 \mathrm{~Hz}, \mathrm{H}-18 \mathrm{a}), 2.95(1 \mathrm{H}, \mathrm{d}, J=11.5 \mathrm{~Hz}, \mathrm{H}-18 \mathrm{~b}), 2.36(1 \mathrm{H}, \mathrm{m}, \mathrm{H}-13), 1.73(3 \mathrm{H}, \mathrm{d}, J=1.0$ $\mathrm{Hz}, \mathrm{Me}-17), 1.05$ (3H, s, Me-20), 0.68 (3H, s, Me-19). ${ }^{13} \mathrm{C}$ NMR (150 MHz, CDCl 3 ) (see Table 1). EIMS: $(\mathrm{m} / \mathrm{z}) 304.2 .0(89 \%)[\mathrm{M}]^{+}$for $\left(\mathrm{C}_{20} \mathrm{H}_{32} \mathrm{O}_{2}\right), 286.2(58 \%)\left[\mathrm{M}-\mathrm{H}_{2} \mathrm{O}\right]^{+}, 273.2(53 \%)\left[\mathrm{M}-\mathrm{CH}_{2} \mathrm{OH}\right]^{+}$, $268.2(7 \%)\left[\mathrm{M}-2 \mathrm{H}_{2} \mathrm{O}\right]^{+}$.

\section{Acknowledgments}

The authors would like to thank Professor John M. Pezzuto (University of Hawai) and Professor David G. I. Kingston (Virginia Polytechnic Institute and State University) for cytotoxic activity facilities. 


\section{ORCID}

Turgut Kilic: 0000-0002-6842-3160

Gulaçtı Topçu: 0000-0002-7946-6545

Ahmet C. Goren: 0000-0002-5470-130X

Zeynep Aydogmus: 0000-0001-7784-0129

Ali Karagoz: 0000-0001-8130-4724

Yaşar K. Yıldız: 0000-0001-5328-1545

Irfan Aslan: 0000-0002-8749-4044

\section{References}

[1] F.Celep and T. Dirmenci (2017). Systematic and biographic overview of Lamiaceae in Turkey, Nat. Vol. Essent. Oil. 4(4), 14-27

[2] K. H. C. Başer and N. Kırımer (2018). Essential oils of Anatolian Lamiaceae, Nat. Vol. Essent. Oil. 5(4), $1-28$

[3] A. Huber-Morath (1982). Sideritis L. In: Flora of Turkey and the East Aegean Islands, ed. by Davis PH, V. 7, University of Edinburgh Press, Edinburgh, pp. 178-199.

[4] M. R. Mill (1988). In: In Flora of Turkey and the East Aegean Islands, ed. by Davis PH, V.7, University of Edinburgh Press, Edinburgh, pp.189-190.

[5] P. H. Davis (1988). Flora of Turkey and East Aegean Islands, Vol.10, University of Edinburgh Press, Edinburgh.

[6] K. H. C. Başer and N. Kırımer (1998). Bazı yeni bitki türleri ve Türkiye Florası için yeni kayıtlar, $T A B$ Bülteni, 13-14, 57-65 (In Turkish).

[7] A. Guvenc, P. J. Houghton, H. Duman, M. Coşkun and P. Şahin (2005). Antioxidant activity studies on selected Sideritis species native to Turkey, Pharm. Biol. 43,173-177.

[8] H. Duman (2012). Sideritis L. In: Türkiye Bitkileri Listesi(Damarlı Bitkiler) ed. by A. Guner, S. Aslan, T. Ekim, M. Vural, \& T. Babaç, Nezahat Gökyiğit Botanik Bahçesi ve Flora Araştırmaları Derneği Yayını, İstanbul, pp. 585-588 (In Turkish).

[9] N. Kirimer, M. Kurkcuoglu, T. Ozek, K. H. C. Baser and G. Tumen (1996). Composition of the essential oil of Sideritis condensata Boiss. et Heldr., Flavour. Fragr. J. 11, 315-317.

[10] M. Tabata, G. Honda and E. Sezik (1988). Report on Tradional Medicine and Medicinal Plants in Turkey, Faculty of Pharmaceutical Sciences, Kyoto University, Japan

[11] U. K. Caliskan, C. Aka and M. G. Oz (2017). Plants used in Anatolian traditional medicine for the treatment of haemorrhoid, Rec. Nat. Prod. 11, 235-250.

[12] B. M. Fraga (2012). Phytochemistry and chemotaxonomy of Sideritis species from the Mediterranean region, Phytochemistry 76, 7-24.

[13] V. Tadic, A. Oliva, M. Bozovic, A. Cipolla, M. De Angelis, V. Vullo, S. Garzoli and R. Ragno (2017). Chemical and antimicrobial analyses of Sideritis romana L. subsp purpurea (Tal. ex Benth.) Heywood, an endemic of the Western Balkan, Molecules 22, 1395.

[14] A. Basile, F. Senatore, R. Gargano, S. Sorbo, M. Pezzo Del, A. Lavitola, , A. Ritani, M.Bruno, D. Spatuzzi, D.Rigano and M.L. Vuotto (2006). Antibacterial and antioxidant activities in Sideritis italica (Miller) Greuter et Burdet essential oils, J. Ethnopharmacol. 107, 240-248.

[15] N. Ezer, G. Usluer, S. Gunes and K. Erol (1994). Antibacterial activity of some Sideritis species, Fitoterapia. 65, 549-551.

[16] A. Villar, M. A. Gasco and M. J. Alcaraz (1984). Anti-inflammatory and anti-ulcer properties of hypolaetin-8-glucoside, a novel plant flavonoid, J. Pharm. Pharmacol. 36, 820-823.

[17] A. Zalzuelo, E. Garcia, J. Jimenez, M. A. Ocete and P. Utrilla (1993). Anti-inflammatory and antiulcerative activity of various species of the genus Sideritis from Alpujjara region of Spain, Fitoterapia 64, 26-30.

[18] F. A. T. Barberan, S. Manez and A. Villar (1987). Identification of anti-inflammatory agents from Sideritis javalambrensis n-hexane extract, J. Nat. Prod. 52, 1088-1091.

[19] N. Ezer, E. Sezik, K. Erol and M. Ozdemir (1991). The antispasmodic activity of some species. Proceedings of the $9^{\text {th }}$ Symposium on Plant Drugs, University of Anatolia, Eskisehir, Turkey.

[20] G. Zengin, C. Sarıürkçü, A. Aktümsek and R. Ceylan (2016). Antioxidant potential and inhibition of key enzymes linked to Alzheimer's diseases and diabetes mellitus by monoterpene-rich essential oil from Sideritis galatica Bornm. endemic to Turkey, Rec. Nat. Prod. 10, 195-206. 
[21] E. Kupeli, F. P. Sahin, E. Yesilada, I. Calis and N. Ezer (2007). In vivo anti-inflammatory and antinociceptive activity evaluation of phenolic compounds from Sideritis stricta, Z. Naturforsch. C. 62, 519-525.

[22] G. Topcu, A. C. Goren, Y. K. Yildiz and G. Tumen (1999). Diterpenes from Sideritis athoa, Nat. Prod. Lett. 14, 123-129.

[23] G. Topcu, A.C. Goren, T. Kilic, Y. K. Yildiz and G. Tumen (2001). Diterpenes from Sideritis argyrea, Fitoterapia 72,1-4.

[24] G. Topcu, A. C. Goren, T. Kilic, Y. K. Yildiz and G. Tumen (2002). Diterpenes from Sideritis sipylea and Sideritis dichotoma, Turk. J. Chem. 26, 189-194.

[25] G. Topcu, A.C. Goren, T. Kilic, Y. K. Yildiz and G. Tumen (2002). Diterpenes from Sideritis trojana, Nat. Prod. Lett. 16, 33-37.

[26] T. Kilic, Y. K. Yildiz, G. Topcu, A. C. Goren, M. Ay, S. G. Bodige and W. H. Watson (2005). X-ray analysis of sideroxol from S. leptoclada, J. Chem. Crystallog. 35, 647-650.

[27] T. Kilic (2006). A new and known diterpenoids from Sideritis stricta Boiss \& Heldr. and their biological activities, Molecules 11, 257-262.

[28] S. Carikci, C. Col, T. Kilic and A. Azizoglu (2007). Diterpenoids from Sideritis tmolea P.H. Davis, Rec. Nat. Prod. 1, 44-50.

[29] T. Kilic, S. Carikci, G. Topcu, I. Aslan and A. C. Goren (2009). Diterpenoids from Sideritis condensata. Evaluation of chemotaxonomy of Sideritis species and insecticidal activity, Chem. Nat. Compound. 45, 918-920.

[30] A. Ertas, M. Ozturk, M. Boga and G. Topcu (2009). Antioxidant and anticholinesterase activity evaluation of ent-kaurane diterpenoids from Sideritis arguta, J. Nat. Prod. 72, 500-502.

[31] G. Topçu, A. Ertaş, M. Ozturk, D. Dinçel, T. Kılıç and B. Halfon (2011). Ent-kaurane diterpenoids isolated from Sideritis congesta, Phytochemistry Lett. 4, 436-439.

[32] S. Carikci, T. Kilic, A. Azizoglu and G. Topcu (2012). Chemical constituents of two endemic Sideritis species from Turkey with antioxidant activity, Rec. Nat. Prod. 6, 101-109.

[33] Z. O. Sagir, S. Çarikci, T. Kilic and A. C. Goren (2017). Metabolic profile and biological activity of Sideritis brevibracteata P. H. Davis endemic to Turkey, Int. J. Food Propert. 20, 2994-3005.

[34] B. Halfon, A.C. Goren, A. Ertas and G. Topcu (2010). Complete ${ }^{13} \mathrm{C}$ NMR assignments for ent-kaurane diterpenoids from Sideritis species, Magn. Reson. Chem. 49, 291-294.

[35] G. Topçu and T. Kusman (2014). Lamiaceae family plants as a potential anticholinesterase source in the treatment of Alzheimer's disease, Bezmialem Sci. 1, 1-25.

[36] I. Aslan, T. Kilic, A. C. Goren and G. Topcu (2006). Toxicity of acetone extract of Sideritis trojana and 7-epi-candicandiol, 7-epi-candicandiol diacetate and 18-acetylsideroxol against stored pests Acanthoscelides obtectus (Say), Sitophilus granarius (L.) and Ephestia kuehniella (Zell.), Ind. Crop. Prod. 23, 171-176.

[37] N. Ezer, M. K. Sakar, B. Rodriguez and M. C. De la Torre (1992). Flavonoid glycosides and a phenylpropanoid glycoside from Sideritis perfoliata, Int. J. Pharm. 30, 61-65.

[38] G. Topcu, G. Tumen, T. Kilıc, A. C. Goren, A. Barla, Z. Turkmen and D. G. I. Kingston (2009). Bioactive Turkish plant extracts and their constituents, In Innovations in Chemical Biology, ed. by Sener B . Chapter 6. Springer, New York, pp. 61-81.

[39] N. Tabanca, N. Kırımer and K. H. C. Başer (2001). The composition of essential oils from two varieties of Sideritis erythrantha var. erythrantha and var. cedretorum, Turk. J. Chem. 25, 201-208.

[40] N. Ezer, R. Vila, Canigueral and T. Adzet (1995). Essential oil of Sideritis lycia Boiss. et Heldr, J. Essent. Oil Res. 7, 183-185.

[41] N. Ezer and Y. Akcos (1995). Flavonoids from Sideritis lycia, Hacettepe Univ. J. Fac. Pham. 15, 81-87.

[42] Y. Akcos, N. Ezer, I. Calis, R. Demirdamar and B. C. Tel (1999). Polyphenolic compounds of Sideritis lycia and their anti-inflammatory activity, Pharm. Biol. 37, 118-122.

[43] C. Dincer, M. Torun, I. Tontul, A. Topuz, H. Sahin-Nadeem, R. S. Goktur, S. Tugrul-Ay and F. Ozdemir (2017). Phenolic composition and antioxidant activity of Sideritis lycia and Sideritis libanotica subsp. linearis: Effects of cultivation, year and storage, J. Appl. Res. Med. Arom. Plant. 5, 26-32.

[44] A. Karagoz, N. Arda, N. Gören, K. Nagata and A. Kuru (1999). Antiviral activity of Sanicula europaea L. extracts on multiplication of human parainfluenza virus type 2, Phytother. Res. 13, 436-438.

[45] A. Karagoz, A. Kimiran and M. Sengezer-Inceli (2002). Search for biological activities in Rana ridibunda (Anura-Amphibia) skin secretion, Biologia 57, 755-759

[46] A. Karagoz, E. Onay, N. Arda and A. Kuru (2003). Antiviral potency of Misletoe (Viscum album ssp. album) extracts against human parainfluenza virus type 2 in Vero cells, Phytother. Res. 17, 560-563.

[47] K. Likhitwitayawuid, C. K. Angerhofer, N. Ruangrungsi, G. A. Cordell and J. M. Pezzuto (1993). Cytotoxic and antimalarial bisbenylisoquinoline alkaloids from Stephania errecta, J. Nat. Prod. 56, 3038 . 
[48] K. D. McBrien, R. L. Berry, S. E. Lowe, K. M. Nedderman, I. Bursuker, S. Huang, S. E. Klohr, and L. Rakicidins (1995). New cytotoxic lipopeptides from Micromonospora sp. fermentation, isolation and characterization, J. Antibiotics. 48, 446-452.

[49] S. Schwikkard, B. N. Zhou, T. E. Glass, J. L. Sharp, M. R. Mattern, R. K. Johnson and D. G. I. Kingston (2000). Bioactive compounds from Combretum erythrophyllum, J. Nat. Prod. 63, 457-460.

[50] D.Y. Hanoglu, A. Hanoglu, H. Yusufoglu, B. Demirci, K. H. C. Baser, İ. Calis and D. Özkum Yavuz. (2020). Phytochemical investigation of endemic Sideritis cypria Post, Rec. Nat. Prod. 14 (2), 105-115.

[51] A. Z. Gonzalez, B. M. Fraga, M. G. Hernandez and J. R. Hanson (1981). The ${ }^{13}$ C- NMR spectra of some ent-18-hydroxykaur-16-enes, Phytochemistry 20, 846-847.

[52] E. Carrera, A. Garcia-Granados, A. S. De Buruaga and J. M. S. De Buruaga (1983). Diterpenoids from Sideritis hirsuta subsp. nivalis, Phytochemistry 22, 2779-2781.

[53] B. M. Fraga, M. G. Hernandez, J. M. H. Santana and J. M. Argeta (1991). Diterpenes from Sideritis ferrensis, Phytochemistry 30, 913-915.

[54] Valverde, S. Huneck (1972). 6 New diterpenes from Sideritis-leucantha Cav. and Sideritis-linearifolia Lam, Tetrahedron Lett. 22, 2187-2188.

[55] P. Venturella, A. Bellino and F. Piozzi (1975). Diterpenoids from Sideritis-theezans, Phytochemistry 14, 1451-1452.

[56] A. Lamiri, S. Lhaloui, B. Benjilali and M. Berrada (2001). Insecticidal effects of essential oils against hessian fly, Mayetiola destructor (Say), Field. Crop. Res. 71, 9-15.

[57] İ. Aslan, H. Ozbek, O. Calmasur and F. Sahin (2004). Toxicity of essential oil vapours to two greenhouse pests, Tetrany cusurticae Koch and Bemicia tabacci Genn. Ind. Crops. Prod. 19, 167-173.

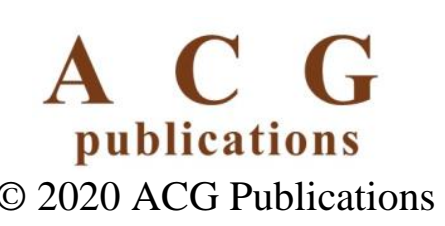

